\title{
SOUTH KOREA CULTURAL HISTORY BETWEEN 1960S AND $2012^{15}$
}

\author{
Mi Sook PARK \\ University of Sheffield \\ School of East Asian Studies \\ Sheffield, UK \\ imhush@gmail.com
}

\begin{abstract}
This paper examines the development of South Korean cultural policy from the 1970s to the present. It contextualises South Korean state, culture and its cultural policy within the framework of state developmentalism, so as to understand their dynamics and relationships. A detailed analysis of how the national cultural policy is interpreted and implemented through institutional practices, historically and in its contemporary context shall be made.
\end{abstract}

Key words: Cultural Policy, developmentalism, South Korea, Hallyu

\section{0 년대부터 2012 년 기간의 한국의 문화정책}

초록: 본 논문은 1970 년부터 현재까지 한국의 문화정책에 관해 분석하였다. 국가발전주의 입장에서 문화정책이 어떻게 실행, 적용되었는지를 각 정권별로 문화정책과 기관을 통해 살펴 보았다. 이런 결과 문화정책은 박정희 정부에서부터 새마을 운동과 같은 근대화 운동을 비롯해 아시아 금융위기 이후 새로운 경제성장의 동력으로 연계되어 있는 것을 나타났다.

15 This paper prepared and edited from my PhD thesis -How "Hallyu" outcome in Asia since the early of 2000s- for the Second International Conference on Korean Humanities and Social Sciences - Language, Literature, Culture and Translation in Adam Mickiewicz University in Poland, $7^{\text {th }}$ to $8^{\text {th }}$ July 2014 
키워드: 문화정책, 발전주의, 한국, 한류

\section{Overview}

This paper examines the development of South Korean cultural policy from the 1970s to the Lee Myoungbak government. It contextualises South Korean state, culture and its cultural policy within the framework of state developmentalism, so as to understand their dynamics and relationships. A detailed analysis of how the national cultural policy is interpreted and implemented through institutional practices, historically and in its contemporary context shall be made.

My focus is the role of the state in cultural development, particularly on the ways institutional practices of cultural policy have contributed to the reconstruction of Korea's national culture and economy since the first military regime of Park Chunghee until the aftermath of the Asian Financial Crisis in 1997. The government of South Korea's first republic had attempted to reposition 'culture' as a tool to recover the nation's identity after Japanese colonisation and Korean War's devastation. The state was instrumental in forming the national cultural movement for modernisation: The Saemaul-Undong (New Community Movement), and to promote the national sport Taekwondo internationally. The cultural policy of this period illustrates the South Korean developmental state project.

The developmental state perspective explains the rapid economic growth and industrialisation of South Korea from the 1960s. However, it tends to consider 'state and culture' as two discrete and distinct spheres even though empirically, they are organically connected. Despite the fact that the South Korean political elite has always adopted the state developmentalist approach in stimulating economic growth and in social transformation, it pays little attention to the correlation between state and its cultural policy.

Thus, the theoretical and empirical focus of this paper is to illuminate the ways in which the state has utilised its cultural policy to 
achieve national goals through the institutional practices of a specific governmental agency and the impact of its central projects i.e., from the Saemaul-Undong to Hallyu ${ }^{16}$. This paper shall illustrate that a close connection exists, particularly in the context of the Hallyu (Korean wave), which has emerged since the Asian Financial Crisis.

\section{Introduction}

The historical perspective is important in the understanding of the cultural industry in contemporary South Korea. There are three objectives in evaluating South Korea's cultural policy historically. They are namely, 1) the affirmation of national identity which began with government of the First Republic, Rhee Syngman (1948-1960), 2) culture as an instrument to strengthen an authoritarian regime from Park Chunghee to Roh Taewoo (1963-1993), 3) culture as a national economic instrument which began with the Kim Youngsam's administration from 1993.

1) The government between 1948 and 1961 could not devise a comprehensive cultural policy that promotes culture and the arts because of Japanese colonial rule from 1910 to 1945 and the destruction of Korea's economy as a result of the Korean War, which took place between 1950 and 1953 (Ministry of Culture and Information 1979). Korea's basic survival was under threat because of Japanese colonisation and the Korean War that eventually led to the partition of the Peninsula into North and South. Despite these circumstances, however, the foremost challenge of Rhee Syngman's first Republic, in relation to Korea's cultural policy, was to resolve the issue of national identity, to overcome 35 years of Japanese influence and the devastation of a three-year war.

\footnotetext{
${ }^{16}$ Hallyu originally refers to the rising popularity of South Korean popular culture i.e. television drama, films and music in Asia. It has helped the country attain celebrity status across the region since the 1990s. However, this term now simply means 'South Korean popular culture' in general.
} 
2) South Korea's first cultural policy was implemented in 1961 . The Park Chunghee government established the Ministry of Public Information, which oversaw movies, theatre and other performance arts, as well as the management of the National Theatre and National Classical Music Institute. A full-scale cultural policy finally came into existence on 24 July 1968 (Ministry of Culture and Information 1973). The Ministry of Public Information began to systematise and centralise all policies and legislatures related to culture to foster a South Korean national identity in order to consolidate the power of the authoritarian regime. Therefore, the first South Korean cultural policy was used to create national and political stability under authoritarian rule while infusing values conducive to the modernisation of Korean nation.

The Fifth Republic represented by Chun Doohwan's authoritarian regime, between 1980 and 1988 was a very dynamic period in terms of South Korea's cultural policy. The state was actively supporting culture and cultural production to promote national pride in preparation for the 1986 Asian Games and the 1988 Summer Olympic Games (Kyong Hyang ilbo 1987). Chun's regime continued to use cultural policy to strengthen its authoritarianism, thus continuing the approach of his predecessor, Park Chunghee.

Roh Taewoo was the last military leader who ruled South Korea between 1988 and 1993. He advocated for 'the age of the common of the people' (Ministry of Culture 1990). In his inaugural speech of February 1988, Roh had stressed that his government should develop a national culture and improve the people's cultural life. Furthermore, the $24^{\text {th }}$ Summer Olympic Games held in Seoul in 1988 was a turning point for the South Korean government in recognising the power of culture and its impact on the international society. After the Games, the Roh government sought to improve the country's cultural exchange with other countries.

3) The recent transformation of cultural policy in South Korea was motivated by economics rather than politics. With the establishment of the first civilian government in 1993, South Korea's cultural policy no longer played its role in upholding domestic political incumbency. Rather, its goal was to make the country more internationally oriented. It was a central part of Kim Yungsam's political cam- 
paign to uplift South Korea's status globally. This was epitomised in his slogan of "Segehwa" (globalisation) (Ministry of Culture and Sport 1993).

With regards to achieving globalisation and the economic value of Kim's cultural policy, his government was a significant turning point for Korea's cultural policy. The most significant policy instituted during his administration was to regard the country's culture and the arts as part of national wealth and to give it highly priority, thus affirming the economic impact of culture. This is especially noticeable in the regime's support for the nation's film industry (Shin 2005).

The Kim Daejung government, for instance, which had experienced the Asian economic crisis in 1998, began to reorganise the country's economy with neo-liberal strategies, corporatist form of policy-making and a cultural policy that was geared towards building a digital society. The last was done through a comprehensive cultural scheme known as "Vision 21", targeting Korea's cultural industries (2001).

While South Korea's economic growth was mainly exportoriented from the 1960s to the 1980s, focusing on the manufacturing sector such as the heavy industries, the economic value of the cultural industry was by and large ignored (Shim D. 2002). However, as seen from the above, subsequent governments had turned the cultural industry into an economically productive sector like any other industries in South Korea.

This paper shall focus on the way Korea's cultural policy was planned and implemented by the various governments since its Third Republic. Each government had devised its cultural policy and methods according to its own conception of culture, preferred economic system, and specific political ideology. However, like all national policies, the cultural policy also had common problems that were institutional, administrative and financial in nature. Nonetheless, each government had succeeded to achieve its cultural aim within its limited budget.

Due to the short history of South Korea's cultural policy, it is difficult to offer an in-depth comparison of each government's cultural policy. Thus, this paper shall first present a chronological account of each government's cultural policy, with relevant empirical highlights. All in all, South Korea's cultural policy has been an important tool for 
each succeeding government. It can be broadly divided into two historical periods distinguished by its attitude towards other countries.

The first was the closed-door period whereby the Korean culture was to be protected and preserved; this was the main characteristics of the Park Chunghee government right through to the Chun Doohwan government. In contrast, the second period was an open- door period beginning from Kim Youngsam administration to Lee Myoungbak government.

The cultural policy from the Third government in 1963 to the Lee Myoungbak government in 2013 can characterised by the state entering into collaboration with other actors but with the government maintaining its dominance in all of these relationships. Whilst the state increasingly controlled the lives of the individuals between 1963 and the early 1990s through regulations and legislations, its attitude and approach as a developmental state has been very different between the period of the military dictatorships right up to the Roh Taewoo government and the period of the civilian governments from Kim Youngsam government to Lee Myoungbak (Cho 2000). In short, the cultural policy over the last sixty years in South Korea can be differentiated by the attitude of the various governments and the differences in their approach towards globalisation, be it closed-door or opendoor.

During the closed-door period, the State's cultural policy was primarily political. The cultural policy was used as a medium to control the Korean society and to protect its citizens from foreign influences. One example was the imposition of "Screen Quota" to protect the domestic film industry (Shin 2005). However, after the central government had accepted the potential of culture in replacing traditional industries, the role of cultural industry on the national economy began to be recognised and affirmed.

This paper examines the various cultural policies and the laws that were passed between 1963 and 2013. Most of the laws related to the cultural policy can be found on the National Assembly website (www.assembly.go.kr). For example, 294 laws and 1169 cultural policies were passed from 1988 to 2013 between Rho Taewoo government and Lee Myoungbak government. The data has been categorised according to laws of Arts, Sports and Tourism, Heritage, and the Cultural Industry. (See table 1) 


\begin{tabular}{|c|c|c|c|c|c|c|c|c|c|}
\hline \multirow[t]{2}{*}{$\begin{array}{l}\text { Gov- } \\
\text { ernment }\end{array}$} & \multirow[t]{2}{*}{ Year } & \multicolumn{2}{|c|}{ Arts } & \multicolumn{2}{|c|}{$\begin{array}{l}\text { Sports and } \\
\text { Tourism }\end{array}$} & \multicolumn{2}{|c|}{$\begin{array}{l}\text { Cultural } \\
\text { Industry }\end{array}$} & \multicolumn{2}{|c|}{ Heritage } \\
\hline & & $\begin{array}{l}\text { num- } \\
\text { ber }\end{array}$ & rate & $\begin{array}{l}\text { num- } \\
\text { ber }\end{array}$ & rate & $\begin{array}{l}\text { num } \\
\text { ber }\end{array}$ & rate & $\begin{array}{l}\mathrm{nu} \\
\mathrm{mb} \\
\mathrm{er}\end{array}$ & rate \\
\hline $\begin{array}{l}\text { Roh } \\
\text { Taewoo }\end{array}$ & 1988 & 1 & 50 & 0 & 0 & 0 & 0 & 1 & 50 \\
\hline & 1989 & 0 & 0 & 2 & 66.7 & 0 & 0 & 0 & 0 \\
\hline & 1990 & 0 & 0 & 0 & 0 & 0 & 0 & 0 & 0 \\
\hline & 1991 & 2 & 66.7 & 0 & 0 & 1 & 33.3 & 0 & 0 \\
\hline & 1992 & 0 & 0 & 0 & 0 & 0 & 0 & 0 & 0 \\
\hline & sub & 3 & 37.5 & 2 & 25 & 1 & 12.5 & 2 & 25.2 \\
\hline $\begin{array}{l}\text { Kim } \\
\text { Young- } \\
\text { sam }\end{array}$ & 1993 & 1 & 20 & 2 & 40 & 2 & 40 & 0 & 0 \\
\hline & 1994 & 1 & 50 & 0 & 0 & 1 & 25 & 1 & 25 \\
\hline & 1995 & 1 & 28.6 & 0 & 0 & 4 & 57.1 & 1 & 14.3 \\
\hline & 1996 & 2 & 20 & 3 & 60 & 1 & 20 & 0 & 0 \\
\hline & 1997 & 2 & 33.3 & 0 & 1 & 1 & 33.3 & 1 & 33.3 \\
\hline & sub & 7 & 29.2 & 5 & 20.8 & 9 & 37.5 & 3 & 12.5 \\
\hline $\begin{array}{l}\text { Kim } \\
\text { Daejung }\end{array}$ & 1998 & 2 & 14.3 & 6 & 42.9 & 3 & 21.4 & 3 & 21.4 \\
\hline & 1999 & 6 & 35.3 & 4 & 23.5 & 5 & 29.4 & 2 & 11.8 \\
\hline & 2000 & 0 & 0 & 0 & 0 & 0 & 0 & 0 & 0 \\
\hline & 2001 & 2 & 20 & 2 & 20 & 5 & 50 & 1 & 10 \\
\hline & 2002 & 1 & 33.3 & 0 & 0 & 14 & 31.8 & 7 & 15.9 \\
\hline & sub & 11 & 25 & 12 & 27.3 & 14 & 31.8 & 7 & 15.9 \\
\hline $\begin{array}{l}\text { Roh } \\
\text { Moo- } \\
\text { hyun }\end{array}$ & 2003 & 4 & 30.8 & 5 & 38.5 & 4 & 30.8 & 0 & 0 \\
\hline & 2004 & 2 & 20 & 2 & 20 & 4 & 40 & 2 & 20 \\
\hline & 2005 & 4 & 30.8 & 4 & 30.8 & 3 & 23.1 & 2 & 10.5 \\
\hline & 2006 & 4 & 21.1 & 3 & 15.8 & 10 & 52.6 & 2 & 10.5 \\
\hline & 2007 & 5 & 20.8 & 9 & 37.5 & 6 & 25 & 4 & 16.7 \\
\hline & sub & 19 & 24.1 & 23 & 29.1 & 27 & 34.2 & 10 & 12.7 \\
\hline $\begin{array}{l}\text { Lee } \\
\text { My- } \\
\text { oung- } \\
\text { bak }\end{array}$ & 2008 & 1 & 11.1 & 3 & 33.3 & 3 & 33.3 & 2 & 22 \\
\hline & 2009 & 4 & 13.3 & 8 & 26.7 & 12 & 40 & 6 & 20 \\
\hline & 2010 & 2 & 16.7 & 2 & 16.7 & 8 & 66.7 & 0 & 0 \\
\hline & 2011 & 13 & 31.7 & 11 & 26.8 & 11 & 26.8 & 6 & 14.6 \\
\hline & 2012 & 1 & 50 & 0 & 0 & 1 & 50 & 0 & 0 \\
\hline
\end{tabular}




\begin{tabular}{|l|l|l|l|l|l|l|l|l|r|}
\hline & sub & 21 & 22.3 & 24 & 25.5 & 35 & 37.2 & 14 & 14.9 \\
\hline & Total & 61 & 24.5 & 66 & 26.5 & 86 & 34.5 & 36 & 14.5 \\
\hline
\end{tabular}

These data explain the various governments' perspective in devising cultural policies that respond to state-led developmentalism in their own way.

The first section of this paper examines how Korea's cultural policy became such an important tool for the government, when it included traditional arts and national heritage-under its regulations. It also examines the various changes and the factors that instigated these changes since the Third Republic of Korea. It also considers a variety of ways in which the cultural industries and cultural markets were affected by the government's cultural policy.

The second section looks at South Korea's cultural policy from time of the civilian governments between 1991 and 2013 and how their cultural policies responded to the rise of the cultural industries during the successive waves of neo-liberal marketisation, and how the respective governments engaged with the new forces in the world media sector.

The final section shall provide some case studies on how the state has supported the building of the cultural industry based on neoliberalism, particularly in its export of culture. Cultural policy will be evaluated from the perspective of state developmentalism based on the data from governmental organisations and publications including, newspapers, as well as interviews that were conducted during my fieldwork in South Korea in 2013. 


\section{Cultural policy over Closed-door period between 1963 and 1990}

\subsection{Third Republic of South Korea (1963-1979)}

When exploring the evolution of the South Korean's cultural policy, it is important to understand it within the context of nation building at the height of the Cold War as well as the international movement against colonialism and imperialism. Similar to many countries in the 1960s, South Korea had experienced drastic social and economic transformation with huge political turmoil including national independence waged by its national liberation movement (Armstrong 2003). The 1960s was also a time of rapid economic growth and industrialisation (Yim 2002). With regards to South Korea's economic development, Park Chunghee's military government had prioritised rapid economic growth from the 1960s to the 1970s. His government (1963-1979) was also crucial in the formation of cultural policy in South Korea.

Whilst Park's regime continued to use some of the former government's rhetoric such as "Guk-nan (national difficulty)" as its ideological tool for control and hegemony, his government went further to hasten and intensify the discourse of "Ban-gong (Anti-Communist)" through the cultural movement (Shim 2010). Interestingly, the Park regime was also seen as the golden age of South Korean film industry (ibid). According to the South Korean film policy expert Park (2005), its cultural policy, in particular, the film policy and the governmental institutions had contributed to the first golden age of Korea's film industry. Hence, this chapter shall answer questions such as "How did the film industry achieve its golden age under the authoritarian military government?" and "What is the relationship between film and the government?" The process by which the governmental-led cultural policy and its organisations were established during Park Chunghee's rule will also be examined. 
Soon after the success of General Park Chunghee's coup d'état, his military began to control South Korea from 1961. The government quickly went on to establish an institutional system, particularly through its state-led cultural policies. Furthermore, the Park authoritarian government used cultural policy to achieve its economic goals and to legitimise his rule. Park Chunghee as the leader of the Third Republic of South Korea began to change many governmental institutions. In particular, Korea's cultural policy and laws were changed within the first few months after the coup (Shim 2012). Indeed, the majority of the laws related to the cultural sector were passed during the 1960s and the Ministry of Culture and Public Information was established in 1962 as part of the government machinery which continued to operate until the 1990s (Shim 2012).

\section{Organisational Reform}

The Park regime upgraded the Office of Public Information established in 1948 under the Rhee Syngman government to the Department of Public Information on 20 May 1961 and expanded it into the Ministry of Culture and Public Information (Munhwa Gongboboo) in 1968. The Ministry of Culture and Public Information (MCPI) as a governmental organisation served as a political tool of coercion through several cultural plans. Particularly, the MCPI was designed to create an explicitly national culture as an important means of cultivating loyalty to the government and to inculcate a sense of belonging to the nation (Ministry of Culture and Information 1979).

In order to strengthen its cultural policy, the Ministry of Culture and Public Information (MCPI) intensified its systematisation of cultural policy by firstly, reorganising the Cultural Property Management Bureau (Munhwachae-gwalriguk) by moving it from the Ministry of Education to the MCPI in 1968. Secondly, the Korean Culture and Arts Foundation (Han'guk Munhwa Yesul Chinhungwon, KCAF) was established in $1973^{17}$.

\footnotetext{
${ }^{17}$ The Korean Culture and Arts Foundation was renamed as Arts Council of Korea in 2005.
} 
Han'guk Munhwa Yesul Chinhungwon (The Korean Culture and Arts Foundation)

With regards to the state-led cultural movement, the Korean Culture and Arts Foundation (KCAF) was an important state-sponsored agency. The KCAF initiated a number of facilities that were open to the public. Official branches and KCAF-sponsored programmes also facilitated the penetration of state ideology in ordinary people's lives (Park 2010).

The KCAF recognised the effectiveness of sponsoring cultural events for the ordinary people as part of state propaganda. It organised promotional programmes in dance, theatre, music, film and literature. However, it became even more strikingly essential as part of the nation's cultural movement, "The Saemaul-Undong (New Community movement)" (Yim 2002).

The Saemaul-Undong was a representative accomplishment of the Park Chunghee government, together with rapid economic growth and industrialisation. It was also a significant key element of the stateled cultural campaign. The movement focused on the "spiritual aspects" of people's lives by improving Koreans' overall standard of living. The Saemaul-Undong set up programmes such as training of employees and housewives to play an active role in fostering social values like, "gun gom (frugality)" and "hyop tong (cooperation)". The KCAF also published a monthly journal entitled, "Munye Chinhung Wolbo (Culture and Arts promotion monthly)" (Yim 2002).

In addition to state-sponsored organisations, the National Film Production Centre (NFPC) was another example of government intervention. The government upgraded NFPC, established in 1948 under the Rhee Syngman government, and promulgated its first film policy, the Motion Picture Law (MPL) in January 1962 (Shim 2010).

The NFPC used to exploit films as a propaganda tool. The NFPC produced and distributed the mandated cinemas such as the "Daehan News" (The Newsreels) that delivered daily information about South Korea and the "Munhwa Young-hwa" (Cultural Films) whereby documentary or feature films were delivered commercially to the public (Shim 2010). Furthermore, the NFPC was responsible for whitewashing the military coup, as well as the despatch of the Korean Army in 
the Vietnam War in 1966. It was also responsible for the interpretation of the military 'revolution' through the "Daehan News" (Lee 1988:143). Furthermore, while the mandated films were already produced by the former government in 1948 and 1958 respectively, these cultural films were given much wider public exposure during Park's regime. For instance, 79,046,162 people attended in $1962^{18}$. With the introduction of the mandatory double-bill policy, the NFPC became a significant film producer. Cultural films by the NFPC increased from 25 in 1961 to 70 in 1961 (NFPC 1994). Indeed, these cultural films continued to be produced until the double-bill policy was finally removed from the new film policy in 1998 (Shim 2012).

\section{Cultural Policy}

The Park government had also launched its cultural policy more proactively by establishing laws. As mentioned above, Park not only upgraded many governmental organisations, for instance, the Office of Public Information to the Department of Public Information in 1968, it had also established the Foundation of Korea Culture and Arts Promotion in 1973 based on the Culture and Arts Promotion Act in 1972, which included literature, fine arts, music, dance, theatre, film, entertainment, traditional music, photography, language and publishing as culture and arts (Yim 2002).

In his inauguration speech in 1971, Park Chunghee announced his vision of using Korea's cultural heritage to help modernise the nation. He used the widely publicised slogan, "Mun-hwa Han'guk ${ }^{19}$ (Cultural Korea)" (Yim 2002). Hence, in 1972, the government designated October as the "Month of Culture" and October 20, 1973 as the "Day of Culture" (Munhwa Gongbo 30 nyeon [Thirty years of culture and public information] 1979: 224)

\footnotetext{
${ }^{18}$ Despite a population of only 26,231,000, according to the Korean Motion Picture Promotion Corp (KMPPC), there was an increase in film viewers per capita by 2.3 times per year. (Korean Motion Picture Promotion Corp 1977: 156).

${ }^{19}$ It is not surprising that the Park administration adopted the slogan, "Cultural Korea" in the exact same characters used in an earlier Japanese slogan, "Bunka Nippon (Cultural Japan)" project (Park 2010).
} 
The Park government initiated the First Five-Year Plan for the revival of Culture and Arts (Munye Chinhung 5-gaeyon kyeheok) from 1974 to 1978, which was the first long-term plan in Korea's cultural policy. The objective was to create a new national culture based on Korea's indigenous values and identity within the framework of the Culture and Arts Promotion Law enacted in 1972 (Ministry of Culture and Information 1973).

This included developing programmes such as the promotion of national studies, propagation of culture to the public, and the introduction of Korean culture overseas. It is worth noting that during this period, the entire budget was supported directly by the government.

\section{Table 2. Investment plan between 1974 and 78 (in million won)}

$\begin{array}{ccccccc} & \text { Total } & 1974 & 1975 & 1976 & 1977 & 1978 \\ \text { Traditional culture } & 14,957 & 2,467 & 3,082 & 2,820 & 3,066 & 3,522 \\ \text { History } & 1,569 & 403 & 290 & 292 & 292 & 292 \\ \text { Traditional Arts } & 670 & 88 & 142 & 145 & 147 & 148 \\ \text { Cultural properties } & 12,718 & 1,976 & 2,650 & 2,383 & 2,627 & 3,082 \\ \text { Contemporary arts } & 6,017 & 1435 & 1096 & 1128 & 1162 & 1196 \\ \text { Literature } & 744 & 123 & 123 & 159 & 163 & 176 \\ \text { Fine Arts } & 650 & 106 & 116 & 116 & 146 & 146 \\ \text { Music } & 2,818 & 563 & 566 & 563 & 563 & 563 \\ \text { Drama } & 907 & 467 & 110 & 110 & 110 & 110 \\ \text { Dance } & 898 & 176 & 181 & 180 & 180 & 181 \\ \text { Popular Culture } & 3,985 & 660 & 1344 & 676 & 662 & 643 \\ \text { Cinema } & 3,235 & 510 & 1194 & 526 & 512 & 493 \\ \text { Publishing } & 750 & 150 & 150 & 150 & 150 & 150 \\ \text { Total } & 24,959 & 4562 & 5522 & 4624 & 4890 & 5361\end{array}$

Source: The First Five-Year Plan for Promotion of Culture and Arts 1974-1978, The Ministry of Culture and Information, October 1973. 
Table 3. The cultural budget 1974 to 1978 (in million won)

\begin{tabular}{|c|c|c|c|c|c|c|}
\hline \multirow[t]{2}{*}{ Year } & \multirow{2}{*}{$\begin{array}{c}\text { Government } \\
\text { Total Budg- } \\
\text { et }\end{array}$} & \multirow{2}{*}{$\begin{array}{c}\text { The } \\
\text { ministry } \\
\text { Total } \\
\text { budget }\end{array}$} & \multicolumn{3}{|c|}{ Budget on Culture } & \multirow{2}{*}{$\begin{array}{c}\text { Public In- } \\
\text { formation } \\
\text { budget }\end{array}$} \\
\hline & & & $\begin{array}{l}\text { Sub- } \\
\text { total }\end{array}$ & $\begin{array}{l}\text { Culture } \\
\text { and Arts }\end{array}$ & Heritage & \\
\hline 1974 & 880,533 & 4,330 & 1,431 & 1,431 & - & 2,899 \\
\hline 1975 & $1,586,931$ & 6,263 & 1,754 & 1,754 & - & 4,509 \\
\hline 1976 & $2,258,512$ & 6,508 & 2,012 & 2,012 & - & 4,496 \\
\hline 1977 & $2,896,956$ & 15,866 & 56,810 & 2,920 & 2,761 & 10,185 \\
\hline 1978 & $3,517,037$ & 23,351 & 12,838 & 5,005 & 7,833 & 10,513 \\
\hline
\end{tabular}

Source: Thirty years of culture and public information 1979.

Throughout the Park regime, cultural plan was an important medium to legitimise his authoritarian rule and to build Korea's national identity. This can be seen from the "Law for the Protection of National Treasures in 1962" and the "Charter of National Education in 1968." "National Ethics Education" was also introduced in schools from 1971 and the Korean Mental Culture Study Centre (Han'guk Chongsin Munhwa Yon'guwon) was established in $1978 .^{20}$

In relation to the regime's cultural plan to build a national identity, the Park administration had consecrated national historical sites and figures (Park 2010). For example, the government had focused on historical Korean memorials such as Gyeongju where the first unification of the warring three nations took place in the Seventh Century. Also, King Sejong who devised the Korean alphabets in the midFifteenth Century, and Admiral Yi Soon-shin who defeated the Japanese troops in the late Sixteenth Century; all became national symbols of modern Korea (Park 2010). In particular, the Park administration subsidised 125 billion won to recover historical sites all over the country (Thirty years of culture and public information 1979: 236).

The state-sponsored cultural movement during Park's regime had contributed to the building of South Korea's nationalism today. As

\footnotetext{
${ }^{20}$ It is renamed Academy of Korean Studies in 1991 along with the establishment of the Korea Foundation to promote Korean Studies around the world.
} 
Smith (1985:181) points out, promoting ethnic identity is most significant in building a modern nation-state; the selection of historical sites and national heroes are an important medium for the Park regime to build Korea's national identity. One example was the preservation of national heritage, not only by opening museums and instituting shortterm cultural policies but also in the creation of a new national culture directly linked to the vision of national development (the Department Public Information 1970: 7).

It is important to note that the Park administration was the first to introduce international cultural promotion through state-sponsorship (Park 2010). In other words, the government had attempted to promote Korean heritage not only nationally but also internationally. For instance, Taekwondo became state-sponsored sports along with the establishment of the International Taekwondo Federation (ITF) in 1966 (Andrew C. Nahm, James Hoare 2004). The government also opened the first overseas Korean Cultural Centre in May 10, 1979 in Tokyo, Japan (Park 2010).

However, in contrast to the traditional heritage scheme, the Park government's attitude toward popular culture was to regulate and control. For example, the film industry came under the Korean Film Laws enacted in 1961 but the law had undergone a series of amendments since then. In particular, the Motion Picture Law (MPL) has guided propaganda features related to military censorship in terms of (1) production control, (2) the importance quota system, (3) script censorship, and (4) the producer registration scheme. The MPL consisted of three components: Producer Registration System (PRS), Import Regulations and Censorship Guidelines (Yi 2002, 2003, Moon and Jun 2011, Shim 2011). Furthermore, the MPL affects not only the production system, in terms of film content but also the market structure of the film industry since its revision in 1961 (Shim 2010). The MPL also had strict control of the funding of film companies, studio facilities, production funds and so on. As a result, the 71 film production companies before the enactment of the MPL were drastically reduced to 16 by the authorities (Lee and Choe1988).

One of the features of the film policy after the amendment of the MPL was censorship. Under the MPL, the Park dictatorial regime had censored Korean films and discouraged productions that were antiestablishment and critical of the government (Lee and CHOE 1988). 
For instance, the film " $O \mathrm{Bal}$ Tan (An Aimless Bullet)" directed by Yoo Hynmok in 1961 and "Chil in-ui Yo poro (7 Female Prisoners)" directed by Lee Man-hee in 1965 were both banned from public showing and confiscated (Lee and Choe 1998). However, while the censorship was very strict against anti-establishment and pro-communist films, action films, melodrama, sleazy and action films flooded the market. Thus, as Heuvel and Everette (1994) argue, film companies played a role in supporting the authoritarian rule in return for monopolising local production and to prevent the import of foreign films. Furthermore, according to Herman and Chomsky, anti-communism is one of the filters through which news were fed to produce propaganda i.e. Communism as the ultimate evil has always been the spectre haunting property owners as it threatens the very root of their class position and superior status (1988:29). Consequently, the MPL was fully exploited by the Park regime to achieve thought control of the people.

Despite the severe media control, the media industry continued to grow into big businesses in the 1970s. The market for newspaper production and sales also steadily improved, both in terms of subscription and in advertising revenue (Kim 1994). Even though newspaper companies were competing with other forms of media such as broadcasting but due to the cross-ownership of both (Joo 1993), the management of both industries had remained largely stable. Consequently, Park's cultural policy was used not only as a political medium but also as a tool to create social values approved by his regime. Soon after Park Chunghee was assassinated in 1979, the military General Chun Doohwan took over the government and ruled from 1980 to 1988. Chun continued to control the public through its cultural policy and to divert the public's attention from politics (Kyong-hayang Newspaper 1987:220).

\subsection{Chun Doohwan government (1980-1988)}

Throughout Chun's regime, the media was controlled by media policies and laws similar to its predecessor. At that time, the government 
had mitigated some of its censorship approach (Sa 2006). Despite some similarities with the former government, the Chun Doohwan government had expanded the cultural industry nation-wide and increased its national budget for cultural development accordingly (Yim 2002). Furthermore, unlike the Park government, the Chun government had supported more of contemporary culture along with active encouragement of sports activities, including the founding of the Korean professional baseball and football leagues (Yim 2002).

\section{Cultural Policy}

South Korean cultural policy encountered another big turning point in the 1980s which ushered in one of the most important reforms in Korean culture and cultural industry (Yim 2002). The change marked the transition from strict governmental control of culture in the 1970s to developmental policy that encouraged the expansion of the cultural industry during the Chun regime (Sa 2006). However, this expansion was different from cultural liberalisation. Rather, the Chun government had remained in control of the mass media through the implementation of the Basic Press Act of 1980 (Jin 2006).

The Chun government announced two comprehensive cultural plans, the "New Plan for Cultural Development (1981)" and the "Cultural Plan in the Sixth Five-Year Plan for Economic and Social Development (1986)" (Yim 2002). Under these plans, the Chun government had aimed to establish a national cultural identity, to promote excellence in the Arts, improve cultural welfare, promote regional culture, as well as cultural exchange with other countries (ibid).

Under these cultural schemes, particularly the entertainment and amusement industries grew rapidly. The cultural policy during the Chun regime was dubbed the ' $3 S$ ' policy, which stands for Sports, Sex and Screen (Kang 2012). For example, the Chun government had actively promoted the media industry, including Film and Television and made all television networks government-owned. Professional sports leagues such as football and baseball was promoted under the slogan, "Prosperity of the nation through sports" (Cho 2008: 243). As a result, the Korean Professional Baseball League (KBL) and $\mathrm{Ssi-}$ Reum (traditional wrestling) were founded in 1982 (Cho 2008). The government had also allowed television stations to provide colour 
television broadcasting. However, the Chun government had also confiscated a private broadcasting system at the same time (Lee and Youn 1995: 58).

Ostensibly, South Korea seemed like a democratic country. However in practice, the society was strictly controlled by successive military regimes. The media is no exception (Youm 1996: 59, Park et al., 2000: 113). Since the establishment of the nation-wide broadcasting system in 1961 by the former military regime, the broadcasting system had always been under the direct control of the government. Moreover, the Chun government not only exploited the media as a political medium like its predecessor, it also begun to intervene in the media market structure (Lee and Youn 1995, Im 2005: 192).

Thus, the South Korean broadcasting was strictly controlled by the government of Chun. It is easy to spot media control in authoritarian societies based on the extent of government-dominated censorship that controls the flow of information to the general public (LaMay 2007:26). While some parts of Korea's cultural industry had expanded, other parts were in fact directly seized by the government and freedom of expression was as a result, curtailed.

\section{Media Law}

The Basic Press Act enacted in 1980 was restrictive and comprehensive, detailing specifically the rights and restrictions of the press (Youm 1996: 59) 21. These laws had resulted in the increase in the

\footnotetext{
${ }^{21}$ The Basic Press Act of Korea is restrictive, rather than protective of press freedom. It makes public responsibility a legal requirement of the press:

1. The press shall respect the dignity and value of human beings and the basic democratic order.
}

2. The press shall perform its public duties by contributing to the formation of democratic public opinions concerning matters of public interest by means of news reports, commentary, and other methods.

3. The press shall not infringe upon the personal honor or rights of an individual or public morality or social ethics.

4. The press shall encourage or praise violence and other illegal actions which disrupt public order. (Basic Act, Article 3) 
power of some capitalist groups in Korean society (Kim 1994). According to Curran, "many privately owned media organizations supported right wing military coups" (2002:221). South Korean media had historically helped the politically powerful and this culture has continued in certain parts of the Korean media industry until today.

Under the Basic Press Act of 1980, the government controlled where correspondents should be stationed in provinces outside of Seoul (Joo 1993). In fact, the Ministry of Information officials were placed in newsrooms all over South Korea to guide and direct the handling of news. Subsequently, this has resulted in self-censorship, as well as a monopolistic structure of the industry since the 1980s (ibid).

The Chun junta, furthermore, began to dominate the public broadcasting system (Lee and Youn 1995). It confiscated private broadcasting systems such as Tong-Yang Broadcasting Company (TBC) and Dong-A to merge with the government-run Korean Broadcasting System (KBS) and also forced another private broadcaster Mun-Hwa Broadcasting Corp (MBC) to sell more than 60 percent of its shares to KBS (ibid). As a result, KBS earned both advertising and licensing fees. Moreover, Korean Christian Broadcasting System (CBS) was forced to limit its broadcasts on the pretext of its religious content (ibid). Given these circumstances, media companies such as KBS and MBC became major power groups, duopolistic in advertising market and supported by authoritarian rule (Chung and Chang 2000: 279).

Chun Doohwan is known as a ruthless dictator due to his role in suppressing numerous civilian protests in the 1980s (Andrew C. Nahm, James Hoare 2004: 45), particularly for his role in the Kwangju massacre (ibid, 46). However paradoxically, while strengthening its political control over media, the Chun regime was also the first to subsidize schemes to improve the cultural life of the people (Yim 2002: 40). The regime expanded its support from traditional and highbrow culture to popular culture. Since the implementation of the First Cultural Plan by the Chun regime, known as the "New Plan for Cultural Development" in 1981, the government had announced two comprehensive cultural plans: the "Promotion of Local Culture Law" in 1984 and the "Cultural Plan in the Sixth Five-Year Plan for Economic and Social Development" in 1986 (ibid). The Chun regime had 
similarly subsidized the construction of local exhibition centres and theatres. For instance, the Opera House in Seoul (Goo 1997:5).

The most important feature of the Fifth Republic's cultural policy was to create a market for the entertainment industries (Lee and Youn 1995: 58-59). Chun's cultural policy had liberalized and marketized Korean popular culture through manipulation and regulation of its cultural policy. In addition, many media companies were merged or closed during his rule. These harsh media policies had inevitably led to a monopoly system that severely restricted the sources of news and newspapers until today (Im 2005: 192).

\subsection{The Beginning of Freedom of Expression (1988-1992)}

The Six Republic of South Korea was ushered in at the wake of the June 1987 popular uprising (Park 2002: 121). Even though President Rho Taewoo also came from the military, his government was largely regarded as a transitional government that led South Korea to democracy (ibid). Freedom of Expression began to increase from 1988 and the government gradually loosened its control over the media. In fact, censorship was eventually eliminated. In response to this freer atmosphere, the media began to criticize the government and filmmakers began to make films on subjects previously forbidden (ibid).

The Roh government first followed the cultural plan of its predecessor, that is the "Cultural Plan in the Sixth Five-Year Plan for Economic and Social Development of 1986" (Yim 2002: 41). However, his government also announced its "Ten-Year Master Plan for Cultural Development" in 1990 (ibid). The most significant cultural policy of the Roh government is its provision of cultural welfare and open door policy to foreign cultural industries (ibid).

The Roh government's primary cultural policy had focused on cultural diversity under his political catchphrase, "culture for all people" (Ministry of Culture 1990). His cultural policy aimed to establish a cultural identity of the nation, to promote excellence of the arts, improve cultural welfare, promote regional culture, facilitate interna- 
tional cultural exchange, develop cultural media and finally, achieve national reunification" (Goo 1997: 7). In this sense, the Roh government emphasized a lot more on cultural welfare and international exchange than the regimes before him.

With regards to cultural right, the Roh administration had released the Basic Press Act in 1987. This law contains no provision of public responsibility for the press, which indicates that his government was attempting to "de-authoritarianize" existing restrictive legal mechanisms. In terms of international exchange, not only had 1988 Seoul Olympics taken place during his regime but he also allowed the direct distribution of foreign films in the country since 1988, as part of his liberalisation plan (ibid).

\section{Organization}

The Roh government reformed the Ministry of Culture in January 1990. Owing to the infamous practices of reporting, the Ministry of Culture and Public Information was replaced under the order of Park (Bae and Lee 2012: 43). The new Ministry consisted of 2 main offices, 4 bureaus, and 18 divisions and it also reformed some institutions to ensure cultural diversity. The National Folk Museum and National Central Library were all reformed and local cultural councils were set up, as well as the Chun-Joo Museum and the National Institution of the Korean Language (Goo 1998: 8).

\section{Cultural Policy}

The first stage of Roh's administration had pursued the cultural plan of the Sixth Economic and Social Development Plan between 1987 and 1991 (Yim 2002). However, since reforming the Ministry of Culture, the government had established a 10-year (1990 - 1999) Cultural Plan under the catch phrase, "culture for all people" (ibid). This plan was not only the first about cultural welfare but also the first to be undertaken by cities and local governments for cultural development in South Korea (O Yang Yel 1998: 60). The cultural plans of the previous governments had tended to focus on control and regulation rather than participation and promotion (ibid). Therefore, the Roh gov- 
ernment's cultural policy represented the first cultural democracy in South Korea.

However, most crucial policy here was the liberalization of the media industry. Besides the appearance of new liberal newspapers such as the Hankyoreh and Kukmin-ilbo in 1988, Segye-ilbo in 1989 and Munhwa-ilbo in 1991, a new media market was also created. Further liberalizing measure was taken to introduce cable television service in 1993 and the Korean film market began to open to the US by this time (Shim 2012).

Clearly, media liberalization had brought exponential economic growth to South Korea at a scale that was unprecedented. Ironically, the film industry also began to shrink during the Roh regime (Park 2002: 124). Ostensibly, Roh had rescinded censorship in film production even though film censors became even wearier of politics. Furthermore, the Ministry of Culture which administered the Public Performance Ethics Committee (PPEC) established by the Park government in 1978 remained under the direct control of the government. It was the Ministry that appointed the PPEC President and the former was required to submit monthly reports about its operations (ibid).

In other words, Korea's film industry was still controlled by the PPEC. For example, the PPEC had deleted part of the film, "What are you going to do tomorrow" (1987, Lee Bong won). As a result, of the domestic films approved for screening, there were only 44 out of 88 in 1988,55 out of 110 in 1989, 52 out of 113 in 1990, 51 out of 121 in 1991, and 45 out of 96 in 1992 (Korean Cinema Yearbook 1989: 14446).

Further, in contrast to other media industries, the reduction of Korea's domestic film industry was caused not only by the censorship of the PPEC but also as a result of the import liberalisation of foreign films (Park 2002: 126). In other words, the government had opened its door to foreign cultural industries. The importing of films and music was officially permitted from 1988 onward (ibid). Thus, the liberalization of the media industry in favour of foreign media industries was a watershed in the country's cultural policy. It was of no coincidence then that the government's cultural policy previously focused on regulation and control had become more developmental.

Korea's cultural policy marked a new turning point with the inauguration of President Kim Youngsam Munmin-Chongbu (civilian 
government) in 1993. There was a swift structural change in the cultural industry consequently. Even though the cultural policy was still state-led and top-down, beginning from the Kim Youngsam government, it became more ardently oriented towards achieving national goal in line with state-developmentalism, which was Republic of Korea Favoured economic policy. The following section will examine what happened to Korea's cultural policy from the developmental state perspective since Kim Youngsam took office right through to Lee Myungbak in 2013.

\section{Open-door period since 1993}

The first civilian government started with Kim Youngsam in 1993 under his political catch phrase, "Creation of a New Korea". He also advocated for improving the status of South Korea globally in his socalled "Segyehwa" (globalisation) policy. Kim Youngsam had globalized Korean culture but his most significant policy was to allow Chaebol (Family-owned large conglomerates) to invest in the cultural sector (Shim D 2002: 340).

The next paradigm change took place during the subsequent administration of Kim Daejung. Kim's government was badly hit by the Asian Financial Crisis in 1998. Under such circumstances, his government had attempted to transform Korea's industrial base from manufacturing to knowledge-based.

Comparing to his predecessor, Kim Youngsam who only saw culture as part of the economy, the Kim Daejung government initiated a new paradigm in the cultural industry through his own brand of cultural policy. South Korea had deepened its infrastructural power and there was a shift of resources, and in turn, its capacity from heavy manufacturing to the creative industry. The cultural sector became one of the major national industries since the Kim Youngsam government (Shim D 2002: 339). In other words, the government began to intervene in culture from a developmentist approach. Furthermore, the Kim Daejung government's cultural policy was sustained by his suc- 
cessor, Roh Moohyun (1998 to 2003) who subsequently enhanced Korea's cultural policy with a whole host of support industries (ibid).

The Roh Moohyun government's cultural policy was somewhat different from Kim Daejung's. While Kim's cultural schemes focused on promoting the cultural industry in relation to an information society based on computer networking and communication infrastructures, the Roh government focused more on cultural welfare by supporting the producers of culture, arts, and the participation of the audience. For example, the Roh government had made cultural vouchers available to those who could not afford in 2004 (The Ministry of Culture and Tourism 2005). In other words, since the state began to promote the cultural industry, the Roh government was the first to increase the accessibility of cultural entertainment to the majority of people. The Roh Moohyun government also continued to foster the export of Korean cultural content along with the establishment of new governmental-sponsored organisations under the Ministry of Culture, Sport and Tourism (MCST) The Lee Myungbak government (2008-2012) represented the peak of promoting Korean cultural industry internationally, targeting advantage of the infrastructures already established by the previous governments (Lee 2013: 191). The following section shall show how the state has played a major role in building Korea's cultural industrial prowess and its export competitiveness since the Kim Young Sam government in 1993 right through to the Lee Myungbak's administration in 2012.

\subsection{Building the cultural industry: Kim Youngsam gov- ernment (1993-1998)}

Since the 1990s, the new political milieu in South Korea including the democratization of the mass media, as well as the liberalizing of its market, Korea has become economically more competitive. Moreover, the country's technological advancement has ushered in a multi-media era. Consequently, South Korean politicians have to rapidly adopt globalization policies (Im 2002: 20). For South Korea to become a 
truly globalised economy, increased industrial competitiveness must be matched by an improvement of its national image and the opening up of the country to foreign market. Under these circumstances, the Kim Youngsam government was the first civilian government to initiate the "Creation of the New Korea" policy.

"Creation of the New Korea" is also known as "Segyehwa (Globalisation)" - the active policy response to a rapidly changing global milieu with increased external pressure to open up the country to foreign competition. The Kim Youngsam government had maintained a neoliberal economic policy in contrast with the former governments' closed and protectionist attitude against foreign competition and intervention. Consequently, a major transition in terms of Korea's cultural policy between being inward-looking and outward looking began to emerge. And Segyehwa was precisely designed to overcome this imbalance. The Kim Youngsam administration had applied Segyehwa politically and socio-culturally to encompass almost all facets of Korean life (Far Eastern Economic Review 1995: 48).

In particular, the film industry became a target for marketing opening pushed by the US government transnational cultural industries including like the Twentieth Century Fox, Warner Brothers, Columbia, UIP and Walt Disney (Shim D 2010: 339, Paquet 2009: 51). Such TNCs have rushed into the South Korean film market since direct distribution of foreign films by foreign distributors became possible. These international film studios quickly set up their branches in South Korea and imported a total of 818 foreign films between 1988 and 2001 (Ministry of Culture and Tourism 2002). Therefore, the crisis in the domestic film industry was both economic and cultural.

Korean political elites began to emphasize the importance of cultural software such as films and music over and above the electronic hardware (Han Gwang-Jub 1994). For example, the Presidential Advisory Board on Science and Technology was keen to point out that the Hollywood film, "Jurassic Park" raked in a profit that was equivalent to the export of 1.5 million Hyundai cars in 1994 (Chosun Ilbo 18 May 1994). This led to a new approach of rapidly developing the Korean cultural industry by Kim. 


\section{Organisation}

The introduction of new governmental institutions by the civilian administration was a remarkable development in modern Korea. The Kim Youngsam administration created the Cultural Industry Bureau within the Ministry of Culture and Sport (MCS) in 1994 (The Ministry of Culture and Tourism 1995). The Bureau comprises of six divisions that oversee the cultural industry: Publication and Newspaper, Broadcasting and Advertising, Film and Video, Interactive Media and, Cultural Content Promotion (ibid). The Cultural Industry Bureau played a major role in reviving the failing domestic cultural industry that includes film, publishing, record and video.

Whereas the MCS had been in charge of cultural administration in general, the Bureau was to encourage the growth of high valueadded sectors within the cultural industry, particularly Youngsangsanup (audio-visual industry). Along with the creation of the new administrative organization, the term Munhwa Sanup (cultural industries) and Youngsang-sanup became the focus of the press and the public. With the Bureau, the government began to actively create new markets for culture. Through it, the government strategically expanded the cultural industry by giving support such as the relaxation of censorship, financial support in terms of tax reduction and infusion of public funds (Parquet 2009: 31).

The Kim Youngsam government's establishment of the Bureau of the Cultural Industry offered a straightforward example of how his cultural policy formation was different from the former governments' even though his was very much a response to the domination of foreign cultural products in the domestic market. As Harvey (2007) and other critical scholars argue, these reforms are part of the global turn to a neo-liberal state settlement. Whereas the cultural policy of the former governments had mainly focused on protecting Korean culture and its market through regulations, Kim's government has shown some effort to strengthen the Korean cultural industry before opening its door to the foreign market. 


\section{Cultural policy}

In order to enhance the domestic cultural industry during his administration, the Kim administration has announced three comprehensive cultural policy plans including,

1) "New Five -Year Plan for Promoting Cultural Development" in 1993,

2) "The Master Plan for Cultural Welfare" in 1996 and

3) "The Cultural Vision 2000" in 1997.

(MCS 1993, 1996, 1997, respectively).

Initially, the New Five-Year Plan for promoting cultural development in 1993 included all governmental plans to develop the cultural industry, which had an impact on many cultural sectors, particularly, the audio-visual industry (Byun 1995: 12, Parquet 2009: 34).

During the Kim Youngsam administration, the first cable television system started to broadcast on twenty-one channels in eight local television stations in 1995 and reached seventy-seven cable stations in 1998 (Nam 2008: 651). Since the former government had passed the Composition Broadcasting Act in 1992, the cable television has been maintaining the technologies while abiding and the Act. For example, the government set Programme Provider (PP) guidelines in 11 areas covering news, films, sports, culture and arts, entertainment, education, music, children, women, transportation and tourism, and religion. This move has encouraged Chaebol to invest in the media business (Nam 2008: 655).

Table 4. The Chaebol invests in the media market

\begin{tabular}{|c|c|c|c|}
\hline Chaebol & \multicolumn{2}{|c|}{ Subsidiary } \\
\hline Samsung & $\begin{array}{c}\text { Samsung Corpo- } \\
\text { ration }\end{array}$ & Catch One & Pay cable channel \\
\cline { 3 - 4 } & Dream Box & $\begin{array}{c}\text { Film importer and } \\
\text { Home video producer, and owned } \\
\text { two film theatre screen }\end{array}$ \\
\cline { 2 - 4 } & $\begin{array}{c}\text { Samsung Elec- } \\
\text { tronics }\end{array}$ & Nices & $\begin{array}{c}\text { Producer of CDs, CD-ROMs and } \\
\text { entertainment films and imported } \\
\text { films }\end{array}$ \\
\hline
\end{tabular}




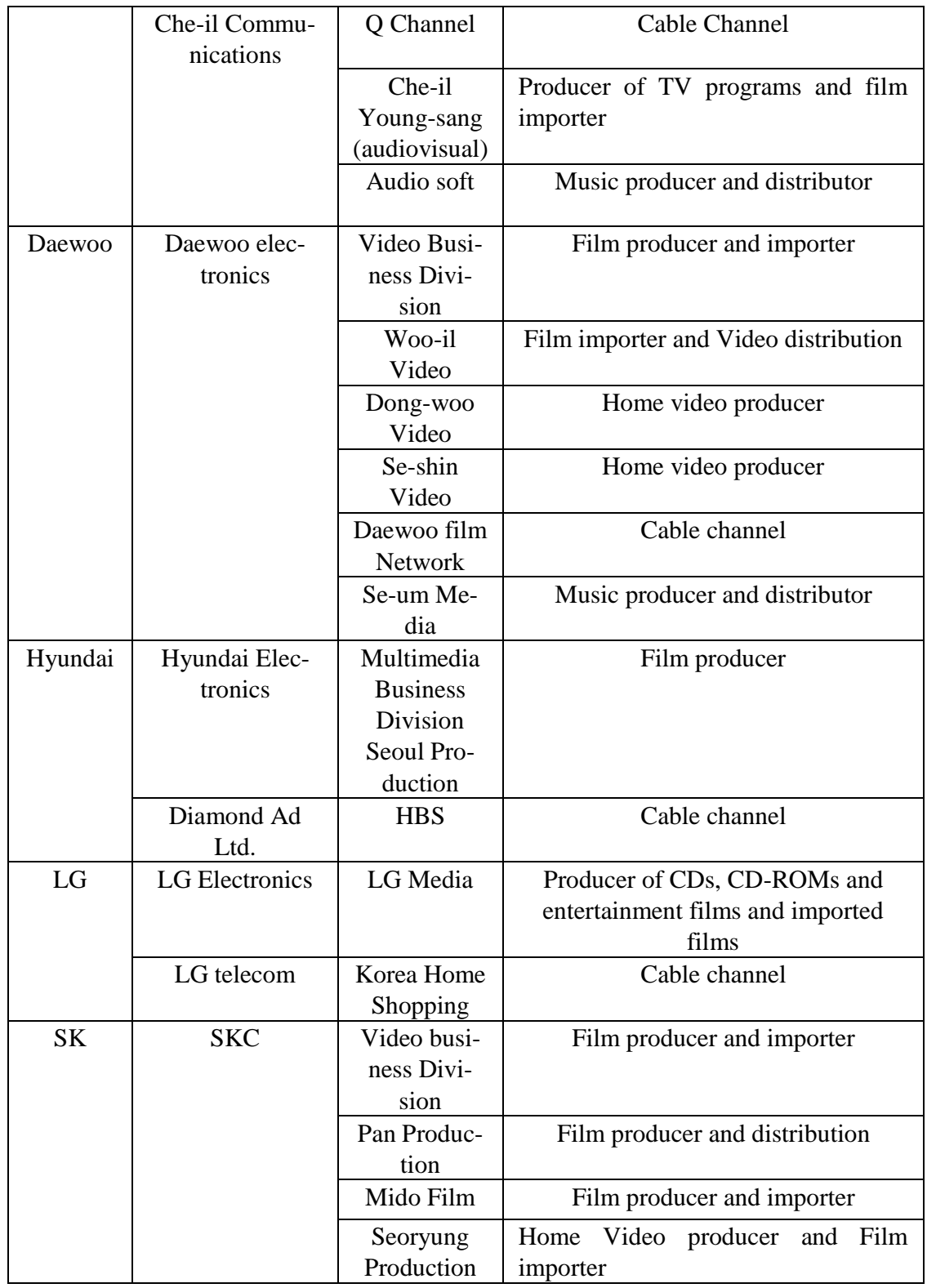

(Source: Shim, 2010). 
The most significant element of Kim Youngsam government's cultural policy was to develop the sector's economic potential, particularly in the audio-visual industry. He also enacted the Motion Picture Promotion Law (MPPL) in 1995 to support the domestic film industry. MPPL also included diverse financial incentives including, tax breaks for film studios to attract Chaebol capital into the film industry (Paquet 2009: 54).

Furthermore, the Kim government began to support the film industry financially. While there have always been some form of cultural policy since the First Republic of Rhee Syngman, it was more a means for the ruling elite to maintain their power by preserving traditions and heritage. The Kim Youngsam government was the first to transform culture into an industry. He had transformed the film industry from a service industry to a semi-manufacturing industry in 1994 and supported it with financial resources (Darlin 1994:82). His rationale was that the new cultural policy would attract new capital, mainly from the Chaebols.

As a result, Chaebol funding flowed into a wide variety of avenues, including the building of cinemas and Korean film production. Chaebols like Daewoo, Samsung, Hyundai, SKC, LG and CheilJedang began to invest in the film industry. While their investment used to be only 20-30 percent of film production costs, they began to put in as much as 100 per cent and even launched their own film production through the MPPL since 1995 (Hwang 2001).

Under these favourable conditions, Daewoo was the first to launch its entertainment division in 1988 to secure the home-video market and cable channel. "Mr. Momma" (1992), "Two Cops" (1994), and "To Top My Wife" (1995) were all directed by Kang Woosuk and fully financed by Daewoo. Samsung also expanded their business in the cultural sector since the early 1990s and launched the Samsung Entertainment Group in 1995 (Kim Myounghwan 1995a). "The Marriage Story" (Kim Uiseok 1992) and "Tae-baeck San-Maek" (Taeback Mountain, Im Kwontaek 1994) were fully financed by Samsung (Hanguk Yeonghwa Sanyp Gujo Bunseok 30). In other words, Samsung and Daewoo's investment in the film industry had increased from partial financial support to 100 percent. Che-il Che-dang as one of the largest good manufacturers in Korea also began to invest in Dream Works by launching its entertainment division in 1996 (Paquet 
2009: 35). Consequently, all these have brought about the formation of new media conglomerates in South Korea today.

Another important outcome of the new cultural policy of the 1990s was the birth of Korean blockbuster films, made possible by financial support from the Chaebol and the government. In addition, the government sponsored national arts schools such as the Korean National University of Arts in 1995 and the Korean Film Academy where film director Bong Joonho was trained. All these were geared towards harnessing human resources for Korea's next-generation in the media industry, as encouraged by the promotion law (Kookmin Ilbo 15 February 1995).

The Kim Yongsam government had effectively begun a new paradigm: a new style of state developmentalism through his cultural policy, particularly in the sector of popular culture. His government had effectively transformed culture into an industry in a short time. Kim Daejung, has ensured that the role of the state become even more deeply and actively involved in the culture industry during his presidency between 1998 and 2003.

\subsection{More Support Less Intervention: Kim Daejung gov- ernment (1998-2002)}

\subsubsection{Promotional strategies}

The Asian financial crisis in the late 1990s may be regarded as another turning point for the cultural policy of South Korea. The crisis had a significant impact on the government's top-down policy approach. Even though Kim Daejung was the first left-wing leader in Korea since the establishment of the Korean state in 1948, his government had actively courted the Chaebol to help Korea overcome the economic crisis (Koo and Kiser 2001: 31). The state's cooperation with the 
Chaebol has eventually led to the recovery of the economy and this shows that the Kim Daejung government continued to pursue state developmentalism by playing a pivotal rule particularly through its cultural policy. His government is also largely credited for upgrading Korea's technical infrastructure (Chosun ilbo Nov 29, 2001).

If not for the fact that the Kim Daejung regime had actively promoted technological development, also in its cultural policy, it would have been difficult for Hallyu (the Korean cultural boom) to be sustained for over two decades. The popularity of Hallyu coincides with the ten-year liberalization of Korea's economy. In fact, the Korean neo-liberal state had successfully reconstructed the national economy by systematically instituting advanced technological programmes and transnational cultural flows to overcome the 1997 financial crisis.

In his inauguration speech in 1998 Kim Daejung had proclaimed a new vision for Korea's recovery from the economic crisis by transforming the country from a manufacturing-based economy into a knowledge-based one, specialized in creative knowledge and information production (Kim Dae Jung 1998). In this context, the Kim Daejung government $(1998$ - 2003) had made the cultural sector one of his prime targets for promoting economic growth. This shall be examined in details in the next section.

\section{Cultural Policy}

The cultural policy of Kim Daejung government not only boosted Korea's cultural export overseas but also used it to transform Korean society (Yim 2002: 41). It has maintained Korea's export-led approach to the country's economic development by systematically expanding it to include the cultural industry, even though traditional academic debate about the developmental state has considered economy and culture to be distinct and separate. However, Kim's administration has proven that the state, economy and culture are interconnected from the developmentalist perspective. His government had instituted four comprehensive cultural schemes:

1) New Cultural Plan in 1998

2) Five Year Plan for the development of the Cultural Industry in 1999 ,

3) The Vision 21 for the Cultural Industry in 2000 and 
4) The Vision 21 for the Cultural Industry in a Digital Society in 2001

(Ministry of Culture and Tourism 1998, 1999, 2000a, 2001 respectively).

The first cultural policy of the government in 1998 had included the "Broadcast Video Promotion Plan". In this scheme, various programmes within the tertiary education programmes were launched to encourage the formation of entertainment talents (Ministry of Culture and Tourism 1998). This is to ensure the continuity of manpower for the next-generation in the media industry. Subsequently, there has been an increase from only 4 Schools in Performing Arts in the Chung-Ang University, Han-Yang University, Dong-Kuk University, and Seoul Art College to 70 schools in 2003 (MCT 2003).

In the second cultural plan, the "Cultural Industry Act" of 1999 provides a legal basis for governmental support and Chaebol involvement in the cultural industry (Shim D 2002:341). The law redefined that the cultural industry to involve planning, development, production, manufacturing, distribution, and consumption of cultural commodities, as well as related services. According to the law, cultural commodities are motion pictures, broadcasting, goods, records/tapes, games, publications or periodicals including, magazines, newspapers, character, comics and multimedia output. Furthermore, the law provides for the establishment of a Cultural Industry Promotion Fund (Paquet 2007). This fund of $\$ 125$ million was to promote Korean cinema between 1999 and 2003 (Dong-A Ilbo 2002:12). Even though this may not seem like a substantial amount of money for the capital-intensive film industry, it is a very significant gesture, albeit still top-down in its approach, of the government to continue to play a leading role in promoting Korea's burgeoning film industry.

Furthermore, given the favourable environment for the film industry assured by government policies, the Korea's Cinema Service launched its first ever e-financing schemes in collaboration with the banking sector and individual capital in the film industry (Paquet, 2001a: 11). For example, the Ha-na Bank launched through the Ha-na Cinema Trust Fund, \$7.8 million in 2001 and an individual-funded programme to allow Koreans to invest in film projects through the Internet in 1999. Individual capital participation in films reached $\$ 85$, 
000 within a short span of 40 days. Such public funding has made hugely successful films such as "Libera me" (Yang Yunho, 2000), "Humanist" (Lee Mooyoung, 2001), and "My Sassy girl" (Kwak Jaeyong, 2001) (Kim Mi-Hee 2002:19, Munhwa il-bo 2002, 15, June).

The Kim Daejung government was the first to provide official financial support and actively promote public funding of filmmaking in Korea, which has subsequently made successful films like "Unhaengnamoo chim-dae" (the Gingko Bed, Kang Jaegye 1996) possible. This film was the second most successful film of the year in Korea with more than 450,000 viewers in Seoul alone. Since its huge success, the government began to ardently encourage and pursue the Chaebols, financial banks, and even individual capital to invest in the domestic film industry.

With the full support of the government, Chaebols started to invest in the film industry on a large scale. For example, the film "Shiri" (Swiri, Kang Jaegye 1999) was the first Korean blockbuster movie funded by Samsung (Maeil Gyungje 1999; Burton 1999). This film not only broke the box office record, it was also the most expensive film made in the history of Korean film industry. Since its success, the production cost of domestic films increased by 167 percent from the average of $\$ 1$ million in 1998 to $\$ 2.67$ million in 2001 (Paquet 2001:11). And young film directors like Kim Jeewon, Kim Kiduk, Kang Jaegyu, Bong Joonho and Hong Sangsoo began to make their mark on the Korean film scene between 1996 and 2000.

Kim Daejung's cultural policy did not only have a profound impact on Korea's entertainment and film industry but also its telecommunication industry, particularly on companies such as Korea Telecom (KT) and SK Telecom. The association of these telecommunication companies with film production has turned out to be a boon for distributors of cultural commodities. For example, KT and SK telecom have facilitated the publicity of these films and helped spread of their content via smart phone, Internet Protocol Television (IPTV) and digital mobile broadcasting (DMB).

With the rapid growth of broadband Internet around the world since the late 1990s, the Kim Daejung administration ardently introduced the concept of an information society in 2000 and utilized Knowledge economy (Kim 2000: 258). However, the concept has focused more on transforming the nation into a knowledge-based 
economy. The Kim administration also began to rely on advanced technology and high value-added industries to boost the Korean economy (Kim and Park 2009).

In particular, the Kim government announced "Vision 21" for the cultural industry in 2000. Despite the long-standing dependence on exports of the Korean economy, his vision was not about specific exports sectors but to integrate exports with high-growth industrial sectors. The integration of cultural products such as films and television dramas with ICT and the electronic industry is a good example. In other words, Korea's contemporary culture is more heavily laden with information technology than its predecessors because of the Internet and the advancement in digital media. In sum, Kim Daejung's government had transformed South Korea into a Post-industrial society through its intervention and support of the cultural industry.

\section{Organisation}

The Kim Daejung administration renamed the Ministry of Culture and Sport as the Ministry of Culture and Tourism in 1998 (Ministry of Culture and Tourism 1998). He also announced a five-year plan to promote the culture industry in the same year and introduced the Basic Cultural Industry Promotion Law in 1999, which was subsequently amended in 2002 (Russell 2008: 122).

Kim's policy scheme had provided for an increase in government budget to promote the cultural market, both domestic and abroad by more than $1 \%$ of the national budget in 2000 , which was the first of its kind in Korean history. This increase had gone primarily into improving the cultural infrastructure of Korea. In addition, there was also an increase from 47.6 billion won $(0.63 \%$ of the total budget) in 1994 to 120 trillion won (1.3\% of the total budget) in 2004 in the national budget on culture (MCT 2008).

Such governmental intervention and increase in the national cultural budget to promote Korea's cultural industry is connected with the establishment and reformation of governmental-sponsored organisations such as the Korean Film Council and the Korean Cultural Content Agency (KOCCA) in 2001 (MCT 2008). The government also funded the Korean Broadcasting Institution (KBI) and the Korean Game Industry Agency (KGIA). The Korea Cultural Contents Agency 
(KOCCA) is in particular, a typical governmental institution set up to enhance government's participation in promoting the cultural industry (MCST 2008).

\section{The Korea Cultural Contents Agency (KOCCA)}

To support Korea's export of culture, the KOCCA was set up in 2001 to foster the growth of Korea's culture content business under the Ministry of Culture, Sports and Tourism. The KOCCA is associated with Korean Broadcasting Institute, the Korea Culture and Content Agency, the Korea Game Development and Promotion Institute, the Culture \& Contents Centre, and Digital Contents Business Group of the Korea Software Industry Promotion. The KOCCA has also opened its branches in Beijing, Tokyo, London and Los Angeles (MCST 2008).

The KOCCA as a governmental cultural policy agency is to encourage and promote South Korean cultural programmes and products abroad (Russell 2008: 122). The KOCCA, both domestic and abroad is supposed to support planning, merchandising, and delivery of Korean cultural content. It is to lay the foundation for content creation, foster market expansion abroad and exports, educate creative talents, develop cultural technology, promote financial investment and loan and maintain a policy framework in collaboration with the Korean Cultural Centre and Korean Tourism Organisation (KOCCA 2007). KOCCA operates as a One Source Multi-Use (OSMU) model and has marketing centres in China, Japan, USA, and Europe since 2001.

The KOCCA governs the cultural industry that was not covered by other public institutes. For example, the agency provides education and training programmes known as, "Korea Content Academy" focusing on content production and business marketing especially in human resource development. The training course is provided both online and offline and there are internship programmes abroad too (Yim, 2005: 12).

The KOCCA not only supports cultural content companies but also gather overseas market information via the Culture Content Export Information System (CEIS). In particular, the KOCCA in China works as a business information centre for the content industry including, Korean Manhwa (Korean animation), character, music, and digi- 
tal content to create a market in China. KOCCA China for instance, has published the Chinese Industry Business Guide in 2007 (KOCCA 2007). This book has been distributed free to Korean content companies interested in entering the Chinese market; it gives an overview of the local cultural industry and legal information such as copyright laws. Even though there has been a boom in Korean drama since the late 1990s in China, China is still an unexplored territory for South Korean content industry. For this reason, the above-mentioned book focuses on explaining Chinese contract process, the documents needed, the relevant authorities to contract, as well as censorship and regulatory policies of China in general. It consists largely two parts. The first half introduces the way to deal with Chinese businesses and the second half of the book explains Chinese law including copyright issues. Since KOCCA also sets up offices in Japan, USA, and Europe, its approaches are different in all these locations.

Since the establishment of the KOCCA Japan office in 2001, it tries to connect South Korean content producers with Japanese marketing manager and fans (Goh 2006). The main aim of KOCCA (Japan) was not only to expand the South Korean content industry market there but also to host various cultural events. For example, KOCCA (Japan) had hosted the Korea-Japan Cultural Contents Seminar, Drama Original Sound Track Korea 2007, and Korea-Japan Visual Business Forum, all to support the promotion of K-Pop in the Japanese market (Digital Times January 2005). The KOCCA (Japan) also published the Entering Japanese Market with Strategic Killer Contents in 2009 (KOCCA 2009). It is a guide to the current trends in the Japanese cultural market and it also provides cases of success and failure in Japan ${ }^{22}$.

\footnotetext{
${ }^{22} \mathrm{http} / / / \mathrm{blog}$. naver.com/ctnews_?Redirect=Log\&logNo=50008646346
} 
The Kim Daejung government had consciously forged a new paradigm of Informational Technology (IT) in Korean society. In comparison with his predecessor, Kim Youngsam, the former had laid the groundwork and framework for the latter. It was the Kim Daejung administration that rapidly developed information and communication technologies and not only that; it facilitated the convergence of media and technology successfully. According to the International Telecommunication Union (ITU) report, "Korea is the leading example of a country rising from a low level of ICT access to one of the highest in the world" (ITU 2003:1).

After the 1997 financial crisis, not surprisingly, exports were regarded as very crucial in protecting the Korea from a financial meltdown. To achieve that, the KOCCA regards culture as content with strong technological implication and with its exportation as the ultimate goal (KOCCA 2004). Furthermore, the techno-economic orientation in Kim Daejung's cultural policy legitimized the promotion of Korea's cultural industry as an integral and critical art of Korea's national economy.

The government had invested approximately 10 billion won annually in the cultural technology development scheme and collaborated with research universities in both engineering, as well as in the fields of humanities and arts (MCT2003). For example, the Korea Advanced Institute of Science and Technology (KAIST) collaborated with the Korea Culture and Tourism Policy Institute (KCTPI) to integrate culture with technology. KAIST published a book, Culture and Arts in the Digital Age in 1999 to introduce core concepts of new economic targets such as bio- technology (BT), environment technology (ET), Nano technology (NT), space technology (ST) and information technology (IT) for the twenty first century. As a result, the term "munhwa kontens" (culture content) was invented and used instead of "Software", "Information", and "digital content" by the KOCCA. The term is officially adopted since 2001 (MCT2003).

The cultural policy of Kim Daejung was interventionist and influential, so much so that it drastically transformed Korea's economy. 
Kim's aim was not merely to export Korean culture such as television drama, film and pop song. His government went beyond the mere commodification and economisation of culture as his predecessor, Kim Youngsam had done. Instead, it had successfully used Korean culture as soft power to stimulate exports (Korea Herald 26 ${ }^{\text {th }}$ Feb 1998).

While culture and exports have become connected since the boom of Korean television drama in the late of 1990s, the Kim Daejung government repositioned culture as a mediator and has successfully transformed the national economy into a knowledge-based one economy. As Nicholas Garnham has argued, creative industry policy is an outcome of information society', regardless of the way culture is combined with technology. However, he is of the opinion that this will not continue. Consequently, Kim's most significant contribution to Korea's cultural policy is its expansion as a national industry, transforming it from a material commodity-based industry to a contentbased industry via quick adoption of modern technology. This has also been dubbed as the "second miracle of the Han River" - a tremendous transformation of South Korea within state developmentalism. (Gibson and Kong 2005: 541).

\subsection{Roh Moohyun government (2003-2008)}

The Roh Moohyun government (2003-2008) succeeded Kim Daejung's policies and faithfully followed his predecessor. Korea's cultural industry indeed had substantially developed by the time Roh took over power. Not surprisingly, the Roh government also expected the cultural industry to improve the national economy and put efforts to enhance cultural education, the culture of equality, cultural diversity and, the development of local culture (MCT2004). Roh emphasized increasing of exports and building cross-cultural ties based on Cultural Technology (CT) with countries such as China and Japan (MCT, 2005). Most of all, Roh's most significant contribution to Korea's cultural policy is its cultural welfare (MCT 2004). 


\section{Cultural Policy}

The government's cultural policy has changed from prohibition and control to expansion and being supportive since the Kim Youngsam government. In fact, Korea's cultural policy was becoming consumerbased. Particularly, the state was keen to export Korean TV dramas and films overseas and the popularity of these is beneficial to its national image. The success of the cultural industry not only generated a positive impact on the entertainment and tourism industries; it also helped boost the sales of Korean commodities. The popularity of television drama overseas such as "Winter Sonata" in Japan and "Daejanggeum" in China has not only boosted Korea's entertainment industry but also derivative industries such as tourism in Korea and consumption of Korean products (MCT 2004).

In this context, the Roh government had pledged his cultural plan four times during his presidency between 2003 and 2008 (MCT 2008). Furthermore, his government succeeded in developing Korea as a brand: another step towards promoting Korea's attractive image abroad.

Roh had announced his first cultural industry plan during his inauguration in February 2003 (MCT 2004). The plan was to link culture with Internet infrastructure. The government was keen to improve digital content as a new generation national business in 2003. Secondly, the government also maintained the existing plan that was laid out by Kim Daejung administration as the vision of cultural industrial policy in December 2003 (MCT 2004). Thirdly, the Roh administration updated the national cultural plan to include "Creative Korea (Chang-ui Hankook in Korean)" in 2004. This scheme was not only to promote the cultural industry but also to expand the Arts into the culture industry. Lastly, the government established a "Cultural Charter" in May 2006 which includes cultural rights such as the enjoyment of culture (MCT 2007).

The first cultural industry policy in 2003 had focused on increasing exports of cultural contents. Comprehensive plan for human resource training was also set up. The new Broadcasting Law was also enacted in 2003 (MCT 2004). The second cultural plan, which was announced in December 2003, was by and large similar to the first one. 
Regarding the policy for Cultural Technology (CT), the government subsidised $\$ 10$ billion to develop the industry (MCT 2006). Along with this, Roh implemented his CT policy under the project, objective to "Ten Million People Internet Education" (ibid). While the scheme centred on the proliferation of cultural creativity and distribution of culture and the industrial utilization of creative work based on the Internet infrastructure, it also included a wide range of programmes to build strong cultural infrastructures (ibid).

Projects under the CT scheme have included traditional content and linking it to the cultural industry. It is called "Cultural Archetype Project" in 2004 (Ministry of Culture ad Tourism and KOCCA 2005). The project aimed to recreate original and traditional Korean cultural content using technological development. It is defined as the "digitalization of material and immaterial cultural properties and the development of archives and multimedia content" (MCT and KOCCA 2005). As a result, the platform "Munhwacontentdotcom" (culture content. com) was set up under the KOCCA in 2004 (MCT and KOCCA 2005).

The government also subsidized 55 billion Korean won for the project to be carried out by the KOCCA (MCT 2006). First, the KOCCA would invite public to bid for contracts to develop culture archetypes to create materials. Second, these applications would be examined by experts from the academe and industries. Third, selected projects would be funded for about two-three hundred million won on the average. Finally, the project outcome would be publicized as prototypes and pilot materials on the World Wide Web (MCT 2002:619). By far, it had produced about 160 items of culture archetypes by 2006 (MCT 2006: 131). The project outcome, which was to produce culture content based on Korean characteristics, had been significant. The institution had provided the needed resources to produce films such as "Wangu-namja" (King and the Clown, 2005), "Welcome to Dongmakgol" (2005), television drama "Joo-Mong" and "Hwang-Jinnie" and online game, "Gue-Sang" (KOCCA 2013).

Overall, the Roh regime had enacted more than 160 laws related to the cultural industrial policy. In May 2003, the Roh government retained the Copyright Act 2003 and set up the Basic Act for Cultural Industrial Promotion in the year. In particular, since the enactment of the Cultural Industrial Promotion Act in 2003, the law was upgraded 
three times in March 2005, April 2006, and July 2007 respectively (MCST 2007). For example in 2006, the Roh government had upgraded the Sound Recording, Video and Game Production Act that was originally enacted in 1999 to adopt a content industry connected environment. The Act includes the promotion of the online gaming industry as one of the strategic national exports and the law on video industry was integrated with the Promotion of Film Act into the Promotion of Film and Video Act. Furthermore, the Recording Act was upgraded to promote the music industry (the institution of Korea Tourism and Culture 2007: 22).

\section{Organisation}

The Roh administration gradually expanded and restructured the Ministry of Culture and Tourism (MCT). MCT had expanded the Department of Cultural Industry since Kim Youngsam government in 1993 into the New Media Team and the Cultural Technology Workforce Team in 2004. In addition, the establishment of the Copyright Industry Team highlights the government's recognition of the commercial importance of copyright protection (MCT 2005). In accordance with the Korean Copyright Commission (KCC), the Roh administration opened a foreign office to protect the rights of South Korean cultural contents business overseas (MCT 2007). Furthermore, the Gaming Industry Team (GIT) was established under the MCT in 2007 for training and education in 2005 (Ministry of Culture, Sports and Tourism 2009). GIT was designed to promote the gaming industry both domestically and internationally (MCST 2009).

In accordance with the Broadcasting Law in 2003, the Korean Broadcasting Commission (KBC) was established (MCT2004). The institution is an independent administrative organization dealing with the administration, regulation and supervision of broadcasting under the Ministry of Culture and Tourism (MCT2004). In order to promote and support cultural contents, the Roh administration had established the department of "Moonhwa-contentdotcom" (culture content) under the KOCCA (KOCCA 2005). The department supported cultural resources in terms of historical research by cultural producers and provided relevant training programmes too (KIM K. B 2006: 7-22). 
According to MCT report (2005), the Roh government's cultural policy had included the promotion of traditional culture under such catch phrases like Han and Han-ji (mulberry paper), Han-bok (Korean traditional dress), Han-ok (Traditional house) as the Han brand. The Ministry also announced the plan to open the Korea Plaza abroad to offer comprehensive services for of the arts, cultural industry, and tourism (MCT 2003). Particularly, the Ministry encouraged the Korean Tourism Organization to screen Korean dramas and films so as to sell Hallyu- related products.

In 2003, the government upgraded the Korea Foundation for Asia Cultural Exchange (KOFACE) into the Korea Foundation for International Culture Exchange (KOFICE) which was sponsored by the MCT, the former having been established by the Kim Daejung government (MCT2003).

\section{Korea Foundation for International Culture Exchange (KOFICE)}

KOFICE aims to nurture the cultural industry in areas such as survey, research, host international forums and seminar annually, particularly on Asian Drama, as well as organizing exchange events between Korea and countries around the world (KOFICE 2003).

Even though KOFICE is not well known, it is set up to support the Korean cultural industry overseas. KOFICE has international correspondents around the world and they are to monitor Korean cultural trends in countries where they are and submit weekly reports about their observation (KOFICE) ${ }^{23}$. These reports are in turn published on the web and in magazines such as Hallyu Dong-hang (Hallyu trend) monthly, quarterly or annually (KOFICE).

The most significant task for KOFICE is to support the Korean culture fan club overseas. This includes financial support for fan activities as s "cultural exchange". The KOFICE also funds activities in less developed countries such as Vietnam, China and Brazil in 2012

\footnotetext{
${ }^{23}$ I have been a UK correspondent of KOFICE since 2013. During my work there, I could not disclose what exactly the KOFICE does for the government in relation to the cultural industry because it is against my contract to do so. However, the general information about the institution can be obtained from its official website: www.kofice.or.kr.
} 
and Laos, Kazakhstan, and Ecuador in 2013. The fund came from the Chaebols such as POSCO, CJ E\&M, CGV, and CJ Na-noom (KOFICE). KOFICE has attempted to become a cultural exchange centre. Besides that, KOFICE hosts the Global Cultural Industry Forum, the Hallyu Forum and the Asia Song Festival since 2004 (KOFICE 2004). In other words, the main goal of KOFICE is to sustain and enhance the popularity of Korean culture overseas.

From the developmental state perspective on culture, Roh Moohyun government tried to develop sound domestic cultural industrial infrastructure including, publishing, media, audio-visual, Online Gaming, Music, Contents (Character, animation) industry and local culture. Roh's efforts not only help promote the cultural industry abroad but it also helped develop the domestic culture industry by boosting the cultural infrastructure nationally. Some examples are: the Audiovisual city in Pusan, Design Fashion city in Daegoo, local cultural industry research centre and local audio-visual media centre in various other places (MCT 2008). The most significant among them is the theme park built by the local government, Hallyuwood in Goyang, Gyeonggi-Do (MCT 2008).

The Roh government had increased the fund injected into the cultural industry from fifty billion won in 1999 (paid for by the former government) to one hundred and ninety billion won in 2006 (MCT 2007). See Graph 1 below:




The Roh Moohyun government has basically continued the cultural policy of its predecessor, which is based on state developmentalism (Lee 2013: 190). According to Jessop who emphasizes knowledge-based economy, such an economy requires the commodification of immaterial goods and services, the application of information and knowledge to the production, and the exploitation of intellectual property (2004: 169). In this vein, the Roh government had moved the knowledge-based economy rapidly forward during its term in office. Most of all, his cultural policy was based on recognizing the importance of the technological development of the Korean economy. It is noteworthy that this policy continued to be adopted by Roh's successor, Lee Myungbak who was from the opposition party, the conservative Grand National Party. In other words, regardless of their ideologies, the ruling elite shared the same view about promoting a post-industrialist view about Korean culture and its role as the state's new engine for economic growth (Lee 2013:199).

\section{Conclusion}

This paper has dealt with the core themes of Korean cultural policy within state developmentalism. It has highlighted examples of how the state controls and supports the development and exports of Korean culture from the Third Republic of President Park Chunghee to President Lee Myoungbak (1963-2013). This chapter has explained closeddoor policies and its relationship to cultural policies and open-door policies and its relationships to cultural policies as well as impact of these different policies on culture. This chapter has illuminated the consistent and pivotal role of the state in driving forward the nation's cultural policies and to boost the exports of Korea's cultural industry, regardless of the change in administrations.

As examined in this chapter, the cultural policy has been profoundly influenced by political upheavals in different periods of Korean history. During the period of closed-policy (1961-1990), the governments used culture to inculcate and consolidate nationhood and 
national unity, especially overcome adversity. Moreover, economic development was prioritised over and above cultural development during this period whereby the focus was on rapid industrialisation to drive forward an export-led economy. This has lasted from 1960s to the late of 1980s in which domestic cultural production was protected from foreign competition by laws.

The early of 1990s finally ushered in the period of open-door policy whereby the Korean cultural policies became integrated with its economy and thereby known as knowledge based economy. From the early of 1990s to 2013, the advent of media globalisation, the deregulation policy of the Kim Youngsam administration, the exports-led supports by the Kim Daejung government and the assistance given by the Lee Myoungbak government to develop the Korean cultural industry has succeeded in promoting Korea's cultural export internationally through intensive media marketisation.

It is clear that the Korean cultural policy has embraced global media marketisation since the Kim Youngsam government more than the earlier governments. However, it is also undisputable the Korean cultural industry has not managed to free itself from government intervention even though government control has gradually reduced as the country transitioned from military dictatorship to electoral democracy. In fact, the cultural policy has so far allowed the government to take the lead in its development. In respect, the Korean government has utilised its cultural policy as medium for social control and national economic development over the past fifty years.

In sum, the Korean cultural policy right from the third Republic to the Lee Myoungbak government can be understood within the context of state-led development as a means of social control to achieve economic prosperity. As Korean cultural policies continue to act as a form of social control and as an engine of for rapid growth in the cultural industry, they did not succeed to make Korean culture more diversified. Nonetheless, as long as cultural commodities are made in the "cultural factory", the commodity cannot exist without its consumers. Consequently, the research on Hallyu also needs to explain the reasons of why Hallyu fan consume Korean media contents. 


\section{Bibliography}

Bae, K. P. L., Min Ah. 2013. "The change of Korea's cultural policy's object and startegy, 1988-2012." The Korean Association for Policy Studies 22 (1): 137-169.

Jin, D. Y. 2006. "Cultural politics in Korea's contemporary films under neoliberal globalization." Media, Culture \& Society 28: 5-23.

Kim, Y. S. 1976. Cultural policy in the Republic of Korea. French, Unesco.

Koo, J., S. L. Kiser. 2001. "Recovery from a financial crisis: the case of South Korea." Economic and Financial Review Fourth Quarter: 24-36.

Kwon, Seung-Ho, Joseph Kim. 2014. "The Cultural Industry Policies of the Korean Government and the Korean Wave" International Journal of Cultural Policy (0): 1-18.

Nahm, Andrew C., James Hoare. 2004. Historical Dictionary of the Republic of Korea. Scarecrow Press.

Nam, S. H. 2008. "The politics of 'compressed development' in new media: a history of Korean cable television, 1992--2005." Media, Culture \& Society 30 (5): 641-661.

Oh, M. S. (1998). "Public Discourse on National Culture and Cultural policy in 1960s and 1970." Cross-cultural Studies (4): 121-152.

Paquet, D. 2009. New Korean cinema breaking the waves. London; New York, Wallflower.

Park, K. K., et al. 2008. "A Study on Ministry of Culture and Tourism's administration". Seoul Association for Public Administration 1: 39-66.

Park, S. H. 2002. "Film Censorship and Political Legitimation in South Korea, 1987-1992." Cinema Journal 42 (1): 120-137.

Park, S. M. 2010. "The Paradox of Postcolonial Korean Nationalism: State-Sponsored Cultural Policy in South Korea, 1965-Present." The Journal of Korean Studies 15: 67-93.

Russell, M. J. 2009. Pop Goes Korea: Behind the Revolution in Movies, Music, and Internet Culture. Stone Bridge Press.

Shim, A. G. 2010. Korean Cinema of Perseverance: Pushing the Boundaries of Quality During the Park Chunghee Authoritarian 
Era, 1961-1970 Media and Performing Arts. University of New South WALES. PhD thesis.

Shim, D. B. 2002. "South Korean Media Industry in the 1990s and the Economic Crisis." Prometheus 20 (4): 337-50.

Shim, D. B. 2006. "Hybridity and the rise of Korean popular culture in Asia". Media Culture Society January 2006 vol. 28 no. 1: 25-44.

Shin, C. Y., J. Stringer. 2005. New Korean Cinema, Edinburgh University Press.

Yim, H. S. 2002. "Cultural identity and cultural policy in South Korea." The International Journal of Cultural Policy 8 (1): 37-48.

\section{Government Documentary and Report}

The Department Public Information 1970.

Ministry of Culture and Information 1973.

Ministry of Culture and Information 1979.

Thirty Years of Culture and Public Information 1979.

Ministry of Culture 1990.

Ministry of Culture, Sports and Tourism 1995 2011.

KOFICE (2005). Culture Industry Report 2004.

KOCCA (2012). Broadcasting Industry White Paper 2011.

KOCCA (2012). Plan for Contents Industry Promotion 2013.

KOCCA (2013). Contents Industry support application.

KOFICE (2013). Global Culture Exchange Forum. 
International Journal of Korean Humanities and Social Sciences, vol. 1/2015 